\title{
Multiple Peptides Converge to Activate the Same Voltage- Dependent Current in a Central Pattern-Generating Circuit
}

\author{
Andrew M. Swensen and Eve Marder \\ Volen Center and Biology Department, Brandeis University, Waltham, Massachusetts 02454
}

The stomatogastric ganglion of the crab, Cancer borealis, is modulated by $>20$ different substances, including numerous neuropeptides. One of these peptides, proctolin, activates an inward current that shows strong outward rectification (Golowasch and Marder, 1992). Decreasing the extracellular $\mathrm{Ca}^{2+}$ concentration linearizes the current-voltage curve of the proctolin-induced current. We used voltage clamp to study the currents evoked by proctolin and five additional modulators [C. borealis tachykinin-related peptide la (CabTRP la), crustacean cardioactive peptide, red pigment-concentrating hormone, TNRNFLRFamide, and the muscarinic agonist pilocarpine] in stomatogastric ganglion neurons, both in the intact ganglion and in dissociated cell culture. Subtraction currents yielded proctolinlike current-voltage relationships for all six substances, and the current-voltage curves of all six substances showed linearization in low external $\mathrm{Ca}^{2+}$. The lateral pyloric neuron responded to all six modulators, but the ventricular dilator neuron only responded to a subset of them. Bath application of saturating concentrations of proctolin occluded the response to CabTRP and vice versa. $\quad N$-(6-Aminohexyl)-5-chloro-1-napthalensulfonamide, a calmodulin inhibitor, increased the amplitude and altered the voltage dependence of the responses elicited by CabTRP and proctolin. Together, these data indicate that all six substances converge onto the same voltage-dependent current, although they activate different receptors. Therefore, differential network responses evoked by these substances may primarily depend on the receptor distribution on network neurons.

Key words: stomatogastric ganglion; crab; Cancer borealis; proctolin; CCAP; RPCH; crab tachykinin-related peptide; FLRFamide-related peptides
Nervous systems contain many neuropeptides and amines that modulate synaptic strength and cellular excitability (Nicoll et al., 1990; Kupfermann, 1991; Marder and Calabrese, 1996; Marder, 1998). Most voltage-dependent ion channels are subject to modulation by one or more substances, and many agonists modulate multiple membrane currents (Kaczmarek and Levitan, 1987; Levitan, 1988, 1994; Hille, 1992, 1994; Gudermann et al., 1997). In principle, the large number of different intrinsic and synaptic currents subject to modulation could provide the potential substrate for virtually infinite modifications of circuit behavior under different modulatory conditions. Nonetheless, there are numerous examples of convergent actions of modulators, in which several substances act on the same current (Dunlap and Fischbach, 1978; Jones, 1985; Christie and North, 1988; Nicoll et al., 1990; Bolshakov et al., 1993; Brezina et al., 1994a,b; van Tol-Steye et al., 1997; Sodickson and Bean, 1998). Convergent actions of modulators may appear to be redundant at the level of the single neuron but may not be redundant at the level of network behavior, if different substances activate different receptors on separate populations of target neurons.

The crustacean stomatogastric ganglion (STG) contains the neurons responsible for producing the well described pyloric and gastric mill rhythms (Selverston et al., 1976; Harris-Warrick et al., 1992). The pyloric and gastric mill rhythms are modulated by a large number of peptides and amines that are present as circulating hormones and/or are released from modulatory projection and sensory neurons (Marder, 1987; Harris-Warrick et al., 1992; Christie et al., 1995; Marder et al., 1995; Marder and Calabrese, 1996). Despite the extensive study of the effects of modulators on the STG motor patterns (Marder and Calabrese, 1996; Marder et al., 2000) only proctolin and the amines have been studied with

\footnotetext{
Received Feb. 22, 2000; revised June 12, 2000; accepted June 26, 2000.

This research was supported by National Institutes of Health Grant NS17813 and the W. M. Keck Foundation. We thank Dr. Jorge Golowasch and Dr. Kathryn S. Richards for helpful discussions and comments.

Correspondence should be addressed to Dr. Eve Marder, Volen Center, MS 013 Brandeis University, 415 South Street, Waltham, MA 02454-9110. E-mail: marder@brandeis.edu.

Copyright (C) 2000 Society for Neuroscience $0270-6474 / 00 / 206752-08 \$ 15.00 / 0$
}

voltage-clamp methods. Proctolin activates an inward nonspecific cation current (Golowasch and Marder, 1992) that shows strong outward rectification with a peak current at approximately $-50 \mathrm{mV}$ and a reversal potential of $\sim 0 \mathrm{mV}$. Additionally, in low external calcium the current-voltage curve for the proctolin-induced current linearizes. Serotonin and dopamine modulate several of the voltage-gated currents in STG neurons (Kiehn and HarrisWarrick, 1992a,b; Harris-Warrick et al., 1995a,b; Zhang and Harris-Warrick, 1995; Kloppenburg et al., 1999).

In this paper we study the effects of six neuromodulators [proctolin, Cancer borealis tachykinin-related peptide Ia (CabTRP), crustacean cardioactive peptide (CCAP), red pigment-concentrating hormone (RPCH), TNRNFLRFamide, and the muscarinic agonist pilocarpine]. These modulators all have excitatory effects at the network level and are able to activate the pyloric rhythm in quiescent preparations (Hooper and Marder, 1984; Marder and Hooper, 1985; Nusbaum and Marder, 1988; Weimann et al., 1993, 1997; Christie et al., 1997b). We show here that these substances appear to activate the same current. However, different target neurons in the stomatogastric ganglion respond to different subsets of these substances. Thus, it is possible that modulators that activate the same membrane current can still elicit different actions at the network level.

Parts of this paper have been published previously in abstract form (Swensen and Marder, 1998).

\section{MATERIALS AND METHODS}

Animals. Experiments were performed on $C$. borealis purchased from Commercial Lobster (Boston, MA). Animals were maintained in artificial seawater at $12-15^{\circ} \mathrm{C}$ until used.

Ganglion recordings. Stomatogastric nervous systems were dissected out of the animals. Extracellular pin electrodes were used to record from nerves, and an Axoclamp 2A amplifier (Axon Instruments, Foster City, CA) was used for intracellular recordings. All preparations were continuously superfused $(3-7 \mathrm{ml} / \mathrm{min})$ with chilled $\left(11-13^{\circ} \mathrm{C}\right)$ physiological saline. Microelectrodes for intracellular recordings were filled with $0.6 \mathrm{M} \mathrm{K} \mathrm{SO}_{4}$ and $20 \mathrm{mM} \mathrm{KCl}$ and had resistances of 20-40 M $\Omega$. Data were collected and analyzed using pCLAMP software (Axon Instruments). Recordings of ganglion neurons in situ were done in two-electrode voltage-clamp (TEVC) or two-electrode current-clamp modes.

STGs were isolated from higher ganglia using a sucrose block of the stomatogastric nerve and/or bath-applied $0.1 \mu \mathrm{M}$ tetrodotoxin (TTX; Alomone Laboratories, Jerusalem, Israel). Neurons were pharmacologi- 
cally isolated using $10 \mu \mathrm{M}$ picrotoxin (PTX; Sigma, St. Louis, MO). The effects of various modulators on the lateral pyloric (LP) and ventricular dilator (VD) neurons were examined. Each STG contains a single LP neuron and a single VD neuron. TTX was used to block action potential generation, and $10 \mathrm{~mm}$ tetraethylammonium chloride (Sigma) was sometimes used in recordings to block some of the $\mathrm{K}^{+}$currents.

Culture recordings. Cultured neurons were recorded using singleelectrode current and voltage clamp using an SEC-05L amplifier from Npi Electronic GmbH (Tamm, Germany). Microelectrodes and data collection and analysis were the same as for ganglion recordings. Cultured cells were unidentified neurons from the STG and were studied 2-4 d after plating.

Culture techniques. STG neurons were plated into dissociated cell culture using minor modifications of previously described methods (Turrigiano and Marder, 1993; Turrigiano et al., 1994, 1995). STGs were removed from the animal, desheathed, and treated at room temperature for $1 \mathrm{hr}$ with $2 \%$ dispase II (Boehringer Mannheim, Mannheim, Germany) in $\mathrm{Ca}^{2+}$ - and $\mathrm{Mg}^{2+}$-free saline. They were then washed at $12^{\circ} \mathrm{C}$ in physiological saline for at least $2 \mathrm{hr}$ and sometimes overnight. Cells were then pulled off the STG by suction using fire-polished electrodes and plated out onto Nunclon culture dishes (Nunc, Naperville, IL) containing culture medium. The medium was composed of sterile Leibowitz-15 (Life Technologies, Gaithersburg, MD) diluted 1:1 with $C$. borealis stock solution and $25 \mu \mathrm{g} / \mathrm{ml}$ gentamycin (Life Technologies). Cultures were incubated $2-4 \mathrm{~d}$ at $12^{\circ} \mathrm{C}$ before recording.

Solutions. C. borealis physiological saline was composed of (in $\mathrm{mm}$ ): $\mathrm{NaCl}, 440 ; \mathrm{KCl}, 11 ; \mathrm{CaCl}_{2}, 13 ; \mathrm{MgCl}_{2}, 26$; Trizma base, 11; and maleic acid, 5, $\mathrm{pH}$ 7.4-7.5. C. borealis stock solution contained (in $\mathrm{mm}$ ): $\mathrm{NaCl}$, 740; KCl, 16; $\mathrm{CaCl}_{2}, 25 ; \mathrm{MgCl}_{2}, 50$; and HEPES, 14, $\mathrm{pH} 7.7$.

Modulators. Proctolin (Sigma), CabTRP Ia (a gift from A. E. Christie and M. P. Nusbaum, Department of Neuroscience, University of Pennsylvania School of Medicine, Philadelphia, PA), CCAP (Bachem, Torrance, CA), RPCH, TNRNFLRFamide (American Peptide Company), and Pilocarpine (Sigma) were dissolved in saline and either pressure-applied using a Picospritzer (5-15 psi, 50-600 msec) or bath-applied by means of a switching port in the continuously flowing superfusion system.

Other chemicals. $\mathrm{N}$-(6-Aminohexyl)-5-chloro-1-napthalensulfonamide $\left(\mathrm{W}-7\right.$; Sigma) was used at $3.3 \times 10^{-4} \mathrm{M}$. The $\mathrm{Ca}^{2+}$ chelator 1,2 bis(2aminophenoxy)ethane- $N, N, N^{\prime}, N^{\prime}$-tetraacetic acid (BAPTA) tetrapotassium salt (Sigma) was injected into cells using electrodes containing 200 mM BAPTA. The protein kinase $\mathrm{C}$ - and cyclic nucleotide-dependent protein kinase inhibitor 1-(5-isoquinolinesulfonyl)-2-methyl-piperazine) dihydrochloride (H-7; Sigma) was bath-applied at $100 \mu \mathrm{M}$. The phospholipase $\mathrm{C}$ and $\mathrm{A}_{2}$ inhibitor 1-(6-((17 $\left.\beta\right)$-3-methoxyestra-1,3,5(10)-trien-17yl)amino)hexl)-1H-pyrrole-2,5-dione (U-73122; Sigma) was bath-applied at $300 \mu \mathrm{M}$.

Current-voltage curves. To obtain $I-V$ curves, voltage-clamped cells were typically ramped from -90 to $0 \mathrm{mV}$ in $1.2 \mathrm{sec}(75 \mathrm{mV} / \mathrm{sec})$. Currents elicited in control conditions were subtracted from currents elicited with the peptide applied to obtain difference $I-V$ curves. Multiple ramps were done during the responses to single puffs or bath application, and the maximal subtracted current during each application was used to characterize the $V_{\text {peak }}$ and amplitude of the response.

\section{RESULTS}

Each STG has a single LP neuron. A large number of neuromodulators, including proctolin, $\mathrm{RPCH}, \mathrm{CCAP}$, TNRNFLRFamide, and CabTRP, cause the LP neuron to increase its excitability during ongoing pyloric rhythms (Marder et al., 1986; Nusbaum and Marder, 1988; Weimann et al., 1993, 1997; Christie et al., 1997b). We were interested in determining the currents that are responsible for this increased excitability in these substances. As a first step, we wished to determine whether each of these substances acted directly on the LP neuron. Therefore, preparations were placed in $10^{-5}$ M PTX, which blocks much of the chemical inhibitory transmission in the STG (Marder and Eisen, 1984), and the modulators applied either in the bath or from puffer pipettes.

Figure 1 shows current-clamp recordings of the same LP neuron in response to short bath applications of each of the six modulators studied here. These recordings illustrate that all of the modulators depolarized the LP neuron and caused it to fire strongly and in some cases to burst. Applications under these recording configurations were done in six preparations for $\mathrm{RPCH}, \mathrm{CabTRP}$, and TNRNFLRFamide and in five preparations for proctolin, CCAP, and pilocarpine. All six modulators were applied to the same preparation a total of three times.

Because there is extensive electrical coupling and there are connections between STG neurons and descending modulatory inputs (Coleman et al., 1995), it is impossible to isolate STG neurons completely from all circuit interactions while in the network. Therefore, we studied the currents evoked by these modula-

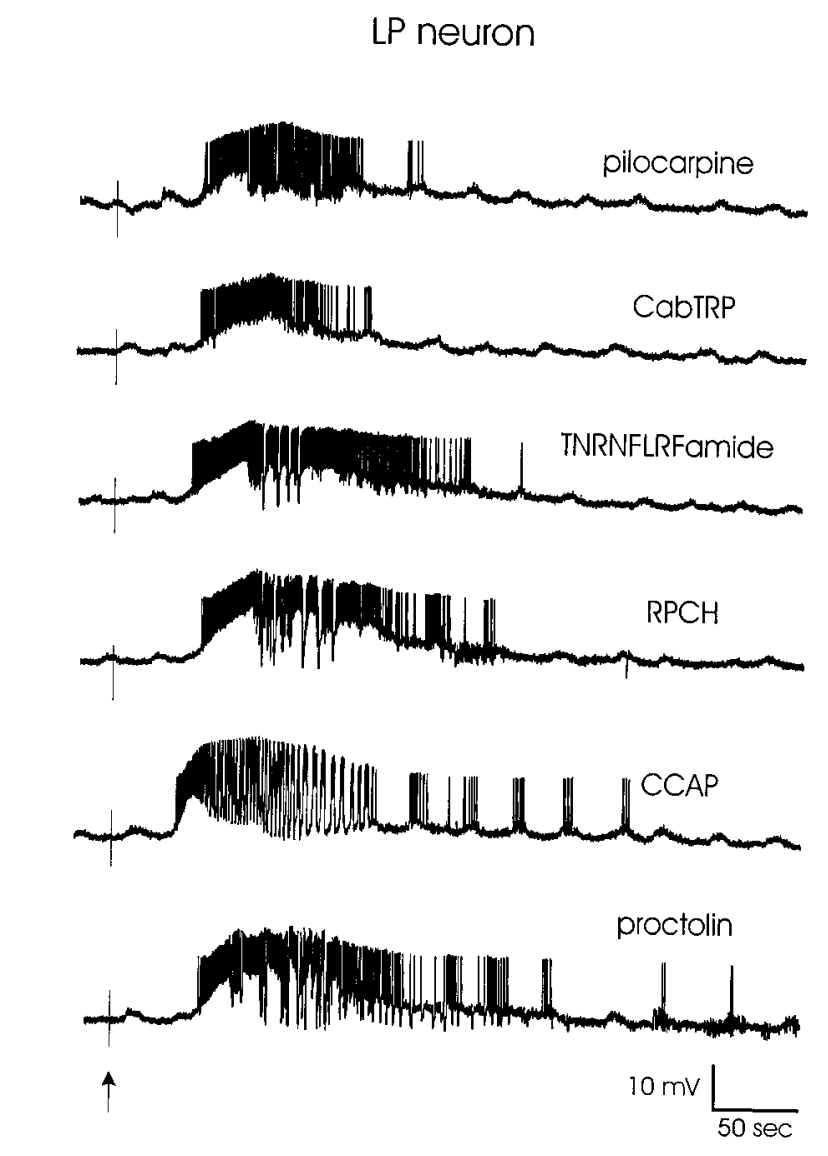

Figure 1. Effects of pilocarpine, CabTRP, TNRNFLRFamide, RPCH, CCAP, and proctolin on a semi-isolated LP neuron. The STG was superfused with $C$. borealis physiological saline containing $10 \mu \mathrm{M}$ picrotoxin to block inhibitory glutamatergic synapses, and the STG was isolated from higher ganglia using a sucrose block of the stomatogastric nerve. Modulators were bath-applied for $45 \mathrm{sec}$ at a concentration of $3 \times 10^{-5} \mathrm{M}$ (pilocarpine), $4 \times 10^{-7} \mathrm{M}$ (CabTRP, TNRNFLRFamide), $3 \times 10^{-7} \mathrm{M}$ (RPCH), or $2 \times 10^{-7} \mathrm{M}$ (CCAP, proctolin). Recordings are all from the same preparation, which was washed for $12-15$ min between applications. The baseline membrane potential for each trace is $-55 \mathrm{mV}$. The vertical arrow indicates the starting time of the modulator bath applications.

tors in individual neurons in dissociated cell culture, as well as in the intact ganglion. The cultured neurons have an additional advantage, because their much reduced electrotonic structure makes it possible to obtain better voltage-clamp control.

Turrigiano and Marder (1993) showed that identified STG neurons retain their characteristic responses to modulators when plated into dissociated cell culture. Specifically, in culture, each identified cell type responded to the same substances to which it responds in the intact ganglion and failed to respond to substances to which it does not respond in the intact ganglion. Because STG neurons must be physiologically identified using intracellular recordings before dissociation, it is extremely difficult to obtain a large number of identified cultured neurons. By combining data on cultured neurons and neurons in the intact ganglion (see below), we were able to verify that the properties of the current we measured in ganglion neurons were not complicated by circuit interactions.

\section{Proctolin activates a voltage-dependent inward current}

In STG neurons, proctolin evokes a small inward current that shows strong outward rectification (Golowasch and Marder, 1992). Figure 2 shows voltage-clamp recordings from an LP neuron in the ganglion that illustrate the characteristic voltage dependence of the proctolin-induced current. In this experiment, the neuron was held at the voltages indicated, and proctolin was pressure-applied at the time indicated by the arrow. The inward current elicited at $-40 \mathrm{mV}$ was larger than the currents elicited at -20 and $-60 \mathrm{mV}$. The 


\section{LP neuron}
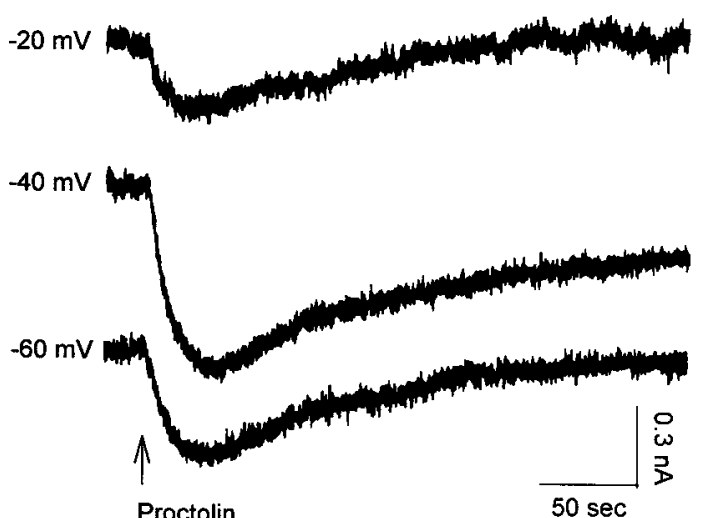

Figure 2. Proctolin elicits an inward current with an unusual voltage dependence. The peak proctolin response in this LP neuron was elicited at approximately $-40 \mathrm{mV}$ and decreased in amplitude for more positive $(-20 \mathrm{mV})$ and more negative $(-60 \mathrm{mV})$ membrane potentials. Proctolin was pressure-applied at $4 \times 10^{-4} \mathrm{M}(400 \mathrm{msec})$ to the STG neuropil. This recording was made using TEVC in the presence of $10 \mu \mathrm{M} \mathrm{PTX}$ and $0.1 \mu \mathrm{M}$ TTX.

voltage dependence of the proctolin-induced current, and specifically the voltage at the peak inward current $\left(\mathrm{V}_{\text {peak }}\right)$, can be seen more clearly using difference currents derived from voltage ramps. Figure $3 A$ shows the total cell currents elicited from a cultured neuron in response to voltage ramps from -90 to $0 \mathrm{mV}$ in the absence and presence of proctolin. The control $I-V$ curve is plotted with a black line, and the $I-V$ curve in the presence of proctolin is plotted with a dotted line. Figure $3 B$ shows the current that results from the subtraction of these two curves. Note that there is a net inward current with a peak at approximately $-18 \mathrm{mV}$ and strong outward rectification. Thirteen of $51(25 \%)$ cultured neurons responded to proctolin with this same characteristic inward current. The remaining cultured neurons showed no response to proctolin. The $\mathrm{V}_{\text {peak }}$ was measured in 7 of these 13 neurons and varied from -15 to $-30 \mathrm{mV}$ (mean, $-25 \pm 5.3 \mathrm{mV}$ ).

\section{Multiple modulators activate a similar inward current}

In addition to responding to proctolin, the neuron shown in Figure $3, A$ and $B$, also responded to CabTRP (Fig. 3C). CabTRP also evoked an inward current with a peak amplitude at $-18 \mathrm{mV}$.

When cultured neurons responded to both proctolin and CabTRP, the differences in the $\mathrm{V}_{\text {peak }}$ values of the two responses were $<5 \mathrm{mV}(n=3)$. Forty-four of 88 cultured neurons tested $(50 \%)$ responded to CabTRP. All neurons that responded to CabTRP did so with the same characteristic inward current. Overall, $\mathrm{V}_{\text {peak }}$ for CabTRP varied from -20 to $-46 \mathrm{mV}$ (mean, $-37 \pm$ $6 \mathrm{mV} ; n=24)$. The difference between the mean $\mathrm{V}_{\text {peak }}$ values of the proctolin and CabTRP currents appear to be attributable to the fact that there were $V_{\text {peak }}$ variations between individual neurons, and only three neurons in the proctolin- and CabTRP-responding populations overlapped.

Golowasch and Marder (1992) showed that the current-voltage curve of the proctolin-induced current linearized in low external $\mathrm{Ca}^{2+}$. We verified that this was the case in the responses of cultured neurons to proctolin (data not shown). Figure 4, top left, shows the current-voltage curve for CabTRP from a cultured neuron in control saline $\left(13 \mathrm{mM} \mathrm{Ca}^{2+}\right)$ and in low $\mathrm{Ca}^{2+}$ saline $(0.1$ $\left.\mathrm{mM} \mathrm{Ca}^{2+}\right)$. In low $\mathrm{Ca}^{2+}$, the current-voltage curve linearized, and there was a large increase in the current amplitude $(n=6)$. Figure 4 also shows examples of the current-voltage curves for TNRNFLRFamide, CCAP, and pilocarpine in control and low-Ca ${ }^{2+}$ saline. The current-voltage curves for TNRNFLRFamide $(n=3)$, CCAP $(n=2)$, RPCH $(n=3)$, and pilocarpine $(n=2)$ all linearized in low $\mathrm{Ca}^{2+}$ saline. These results demonstrate that all of
A

\section{currents elicited from voltage ramps}

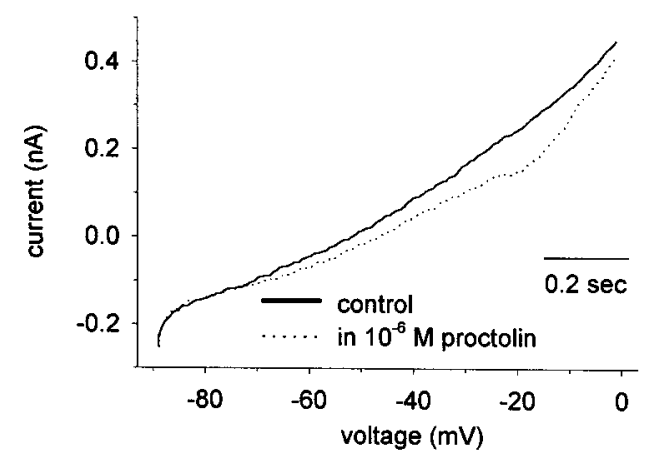

B
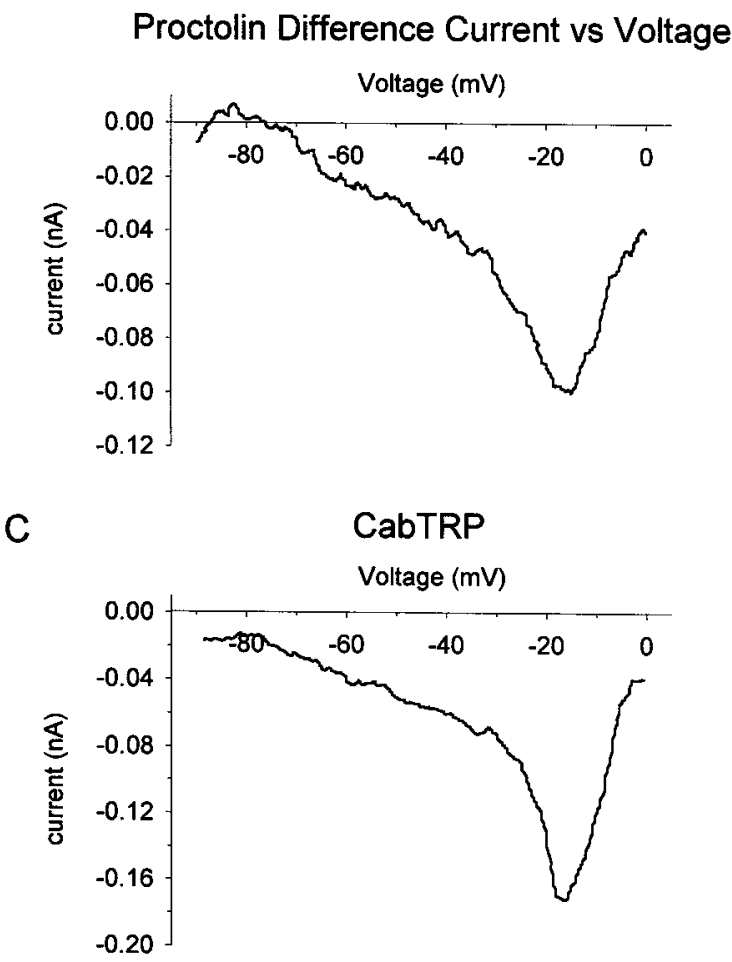

Figure 3. Proctolin and CabTRP currents in an unidentified cultured stomatogastric neuron. $A$, Total cell currents elicited in response to voltage ramps from -90 to $0 \mathrm{mV}(75 \mathrm{mV} / \mathrm{sec})$ in the absence (solid line) and presence (dotted line) of bath-applied proctolin. $B$, Proctolin $I-V$ curve obtained by subtracting the total cell currents elicited by the voltage ramps in $A$. $C$, CabTRP difference $I-V$ curve from the same neuron as in $A$.

these substances activate a current with the same general features, suggesting that they activate the same current.

Figure 5 shows current-clamp recordings from a single cultured neuron that responded to CabTRP, proctolin, TNRNFLRFamide, and CCAP. Each of these substances evoked similar changes in the activity of the cell, showing that completely isolated neurons do respond similarly in response to the multiple modulators that activate the same current. Most of the individual cultured neurons, however, were only tested for responses to a small subset of the six modulators, making it impossible to draw any quantitative conclusions about the frequency of coexpression of the various modulator receptors.

The LP neuron responds to all six of these substances with the same current

All six of the modulators tested elicit the same current in the LP neuron in the intact STG. Figure $6 A$ shows the current-voltage 

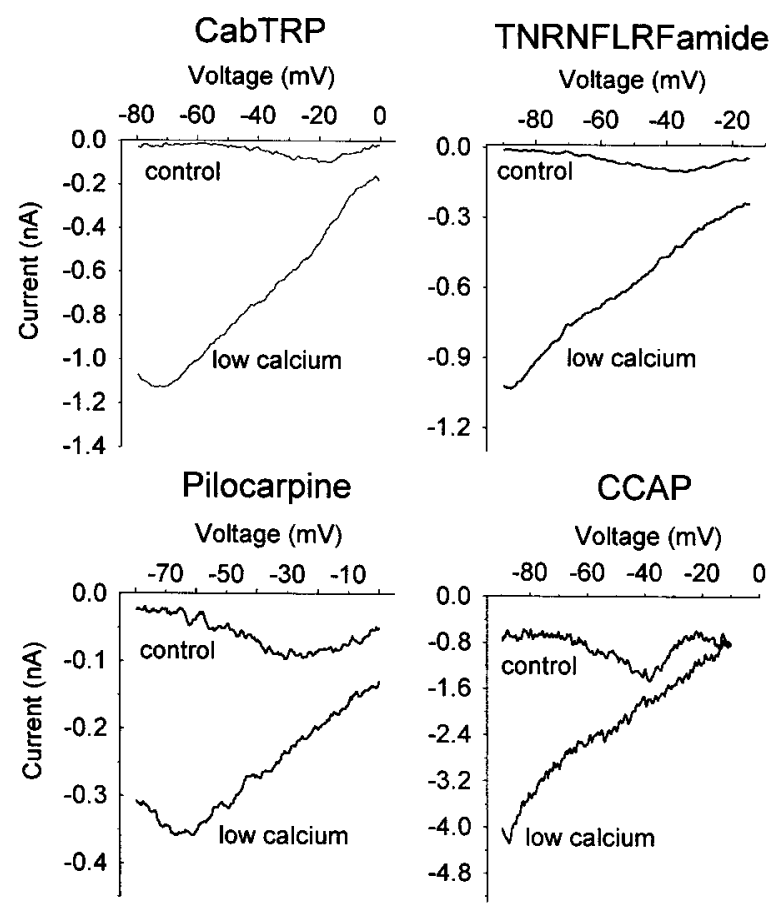

Figure 4. Linearization of $I-V$ curves for CabTRP, TNRNFLRFamide, pilocarpine, and CCAP in low external $\mathrm{Ca}^{2+}$. Control $I-V$ curves were obtained in normal external $\mathrm{Ca}^{2+}(13 \mathrm{mM})$. Low-calcium saline contained $0.1 \mathrm{mM} \mathrm{Ca}^{2+}$. Curves for CabTRP, TNRNFLRFamide and pilocarpine were obtained from SEVC recordings of cultured neurons. The CCAP curve was obtained from a TEVC recording of the LP neuron (semi-intact preparation) in the presence of $10 \mu \mathrm{M}$ PTX and $0.1 \mu \mathrm{M}$ TTX. In each individual graph, control and low- $\mathrm{Ca}^{2+}$ responses are from the same neuron. Each graph, however, shows results from a separate neuron. CabTRP $\left(10^{-6} \mathrm{M}\right)$, TNRNFLRFamide $\left(10^{-6} \mathrm{M}\right)$, and pilocarpine $(3 \times$ $\left.10^{-5} \mathrm{M}\right)$ were bath-applied. CCAP $\left(10^{-4} \mathrm{M}\right)$ was pressure-applied to the ganglion neuropil.

curves for proctolin, CabTRP, CCAP, and RPCH taken from the same LP neuron. Note that each evoked an inward current with a $\mathrm{V}_{\text {peak }}$ between -50 and $-40 \mathrm{mV}$. TNRNFLRFamide and pilocarpine (data not shown) had similar $I-V$ curves for this LP neuron. The currents evoked by each of these substances showed the same characteristic linearization in low external $\mathrm{Ca}^{2+}$ (data not shown). Table 1 shows the properties of the currents evoked by each of the substances in LP neurons. The $\mathrm{V}_{\text {peak }}$ of the currents evoked by each of these substances were statistically indistinguishable (one-way ANOVA, $p=0.078$ ). The LP neuron always responded to each of these substances whenever they were applied.

\section{The VD neuron responds to a subset of the substances}

Unlike the LP neuron, the VD neuron does not respond to CCAP $(n=4)$ or RPCH $(n=5)$. The VD neuron does respond to the remaining four substances (proctolin, CabTRP, TNRNFLRFamide, and pilocarpine), which all elicit currents with the same characteristic $I-V$ curve. Figure $6 B$ shows examples of the $I-V$ curves for proctolin and CabTRP in a VD neuron.

The subtraction currents for CCAP and $\mathrm{RPCH}$, which do not activate a current in the VD neuron, are also shown. The $\mathrm{V}_{\text {peak }}$ of the current seen in response to the modulators in the VD neuron was close to $-20 \mathrm{mV}$ (Table 2), considerably more depolarized than that seen in the LP neuron. The $\mathrm{V}_{\text {peak }}$ values of the currents in these VD neurons evoked by the different modulators were statistically indistinguishable (one-way ANOVA, $p=0.430$ ). However, $\mathrm{V}_{\text {peak }}$ values measured in the $\mathrm{VD}$ and LP neurons were statistically different ( $p<0.001$, Student's $t$ test). The VD neuron always responded to this same subset of peptides.

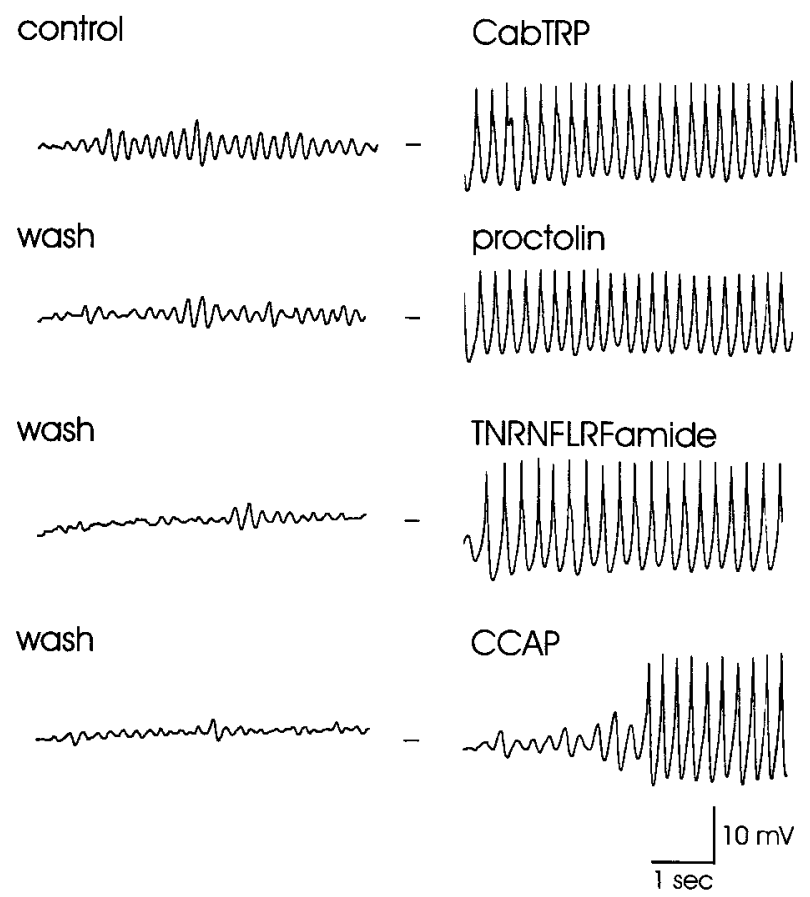

Figure 5. CabTRP, proctolin, TNRNFLRFamide, and CCAP all elicited similar effects in this cultured neuron. Modulators were bath-applied at $10^{-6} \mathrm{M}$, and responses were recorded in current clamp. The neuron was depolarized using a constant current injection to trigger membrane oscillations. The horizontal line indicates $-20 \mathrm{mV}$.

\section{Coapplication of CabTRP and proctolin to LP results in occlusion}

If multiple modulators converge on the same set of ion channels, one would expect that saturating concentrations of one modulator would occlude responses to a second modulator. We tested this using proctolin and CabTRP. We found that saturating concentrations of proctolin and CabTRP resulted in occlusion of the response to the other peptide. We first performed experiments to obtain dose-response curves for the two peptides. In these experiments, the LP neuron was voltage-clamped to $-40 \mathrm{mV}$, the peptides were bath-applied, and the currents were recorded. Figure $7 \mathrm{~A}$ shows an example of the currents resulting from $3 \times 10^{-8}, 3 \times$ $10^{-7}$, and $3 \times 10^{-6} \mathrm{M}$ proctolin, respectively, from one experiment. Figure $7 B$ shows the plotted mean dose-response curves for proctolin and CabTRP $(n=5$ for proctolin and $n=3$ for CabTRP). As calculated from the fits, $90 \%$ saturation was reached at $1.8 \times 10^{-6} \mathrm{M}$ proctolin and $2.0 \times 10^{-6} \mathrm{M}$ CabTRP.

Figure $8 A$ shows the current evoked by a proctolin puff in control conditions and in the presence of $2 \times 10^{-6} \mathrm{M}$ bath-applied CabTRP. Note that the steady inward current evoked by the bath application of the CabTRP was slightly larger than that of the proctolin puff in control conditions, and the response evoked by the proctolin puff during the CabTRP response was virtually occluded $(n=3)$. Figure $8 B$ shows the reverse experiment, in which CabTRP was applied first in control saline and then during a bath application of $2 \times 10^{-6} \mathrm{M}$ proctolin. Again, the response to the puff was occluded when it was applied with a near-saturating concentration of the other peptide in the bath $(n=3)$.

\section{W-7 augments the proctolin and CabTRP currents and alters their voltage dependence}

It would be of obvious interest to determine the identity of the second messenger systems involved in the activation of this channel by the modulators. Therefore, we tried a number of pharmacological agents known to influence second messenger signaling pathways in other species. BAPTA $(n=4)$ gave ambiguous results. H-7 $(n=2)$ and U-73122 $(n=2)$ had no apparent effect. However, the calmodulin inhibitor W-7 (Hidaka et al., 1980; Itoh and Hidaka, 
A

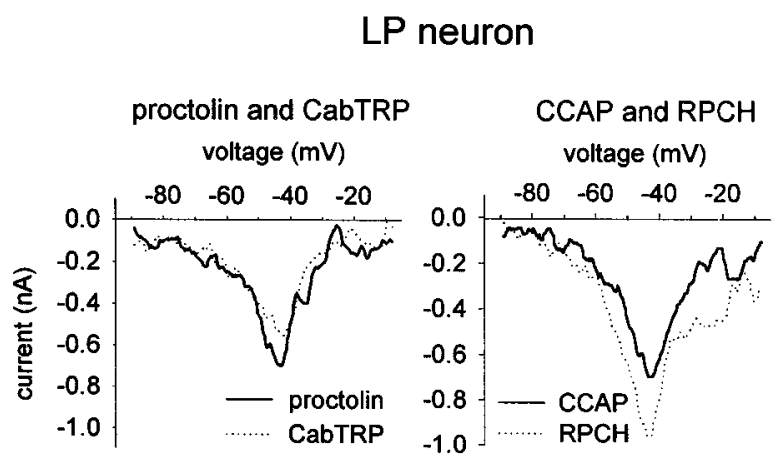

B

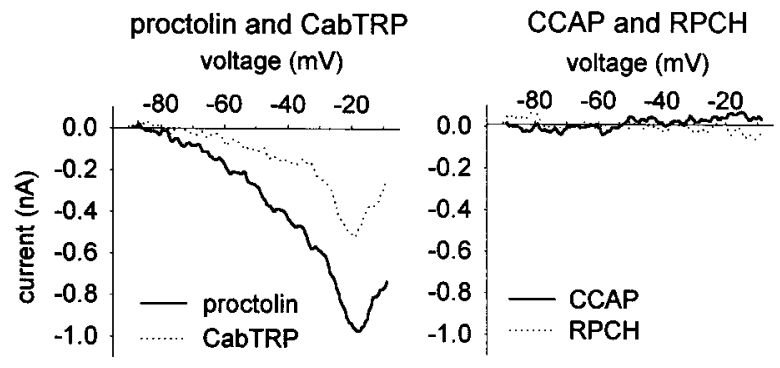

Figure 6. Convergence of modulators onto the LP and VD neurons. $A$, $I-V$ curves for proctolin, CabTRP, CCAP, and RPCH from an LP neuron. All yielded similar $I-V$ curves with their peak currents occurring at very similar voltages (approximately $-45 \mathrm{mV}$ ). Recordings are from the same LP neuron. $B, I-V$ curves for proctolin and CabTRP from a VD neuron with peak currents occurring at similar voltages (approximately $-20 \mathrm{mV}$ ). Unlike the LP neuron, the VD neuron shows no response to RPCH or CCAP. Recordings are from the same VD neuron. Modulators were pressure-applied at $10^{-4} \mathrm{M}$ to the ganglion neuropil. The LP and VD neurons also responded to TNRNFLRFamide and pilocarpine (data not shown) with currents similar to those shown. Recordings were made using TEVC in the presence of $10 \mu \mathrm{M}$ PTX, $0.1 \mu \mathrm{M}$ TTX, and $10 \mathrm{~mm}$ tetraethylammonium chloride.

\section{Table 1. Characteristics of the modulator currents in the LP neuron}

\begin{tabular}{lrrr} 
Modulator & \multicolumn{1}{c}{$n$} & $I_{\text {peak }}(\mathrm{nA})$ & $\mathrm{V}_{\text {peak }}(\mathrm{mV})$ \\
\hline Proctolin & 18 & $-1.2 \pm 0.6$ & $-38.0 \pm 6.0$ \\
CabTRP & 13 & $-1.3 \pm 0.7$ & $-41.8 \pm 4.7$ \\
TNRNFLRFamide & 3 & $-0.6 \pm 0.2$ & $-40.7 \pm 5.9$ \\
CCAP & 6 & $-1.6 \pm 0.9$ & $-37.0 \pm 3.9$ \\
RPCH & 7 & $-1.0 \pm 0.4$ & $-33.9 \pm 6.0$ \\
Pilocarpine & 3 & $-1.1 \pm 0.6$ & $-37.0 \pm 7.5$ \\
Averages for all LP neurons & 35 & $-1.2 \pm 0.6$ & $-38.4 \pm 5.2$
\end{tabular}

$I_{\text {peak }}$ is the mean peak current elicited, and $\mathrm{V}_{\text {peak }}$ is the voltage at which $I_{\text {peak }}$ occurred. For the different modulators, there is not a statistically significant difference in $\mathrm{V}_{\text {peak }}$ measurements from the LP neuron $(P=0.078$, one-way ANOVA). Values are means \pm SD.

1984) had a robust effect on the current. Bath application of $3.3 \times$ $10^{-4} \mathrm{M} \mathrm{W}-7$ increased the amplitude of the currents evoked by both proctolin and CabTRP in the LP neuron. The most interesting aspect of this effect is that W-7 also altered the voltage dependence of the currents (Fig. 9). In this experiment, proctolin puffs were applied in control saline at both -40 and $-80 \mathrm{mV}$. Note that the control response at $-80 \mathrm{mV}$ was smaller than that at $-40 \mathrm{mV}$ (consistent with the characteristic $I-V$ curve of this current). However, in W-7 the amplitude of the response at $-80 \mathrm{mV}$ was much larger than that at $-40 \mathrm{mV}(n=3$ preparations $)$. Similar data were obtained with CabTRP ( $n=3$ preparations).
Table 2. Characteristics of the modulator currents in the VD neuron

\begin{tabular}{lcll} 
Modulator & $n$ & $I_{\text {peak }}(\mathrm{nA})$ & $\mathrm{V}_{\text {peak }}(\mathrm{mV})$ \\
\hline Proctolin & 6 & $-1.1 \pm 0.4$ & $-20.3 \pm 2.9$ \\
CabTRP & 5 & $-0.9 \pm 0.5$ & $-21.2 \pm 4.9$ \\
TNRNFLRFamide & 8 & $-0.8 \pm 0.2$ & $-22.8 \pm 5.4$ \\
CCAP & NR $(n=4)$ & N/A & N/A \\
RPCH & NR $(n=5)$ & N/A & N/A \\
Pilocarpine & 5 & $-1.2 \pm 0.5$ & $-18.6 \pm 3.5$ \\
Averages for all & 13 & $-1.0 \pm 0.5$ & $-20.3 \pm 2.9$ \\
$\quad$ VD neurons & & & \\
\hline
\end{tabular}

$I_{\text {peak }}$ is the mean peak current elicited, and $\mathrm{V}_{\text {peak }}$ is the voltage at which $I_{\text {peak }}$ occurred. For the different modulators, there is not a statistically significant difference in $\mathrm{V}_{\text {peak }}$ measurements from the VD neuron ( $p=0.430$, one-way ANOVA). There is, however, a statistically significant difference between the $V_{\text {peak }}$ measurements for the LP (Table 1 ) and the VD neuron ( $p<0.001, t$ test). Values are means \pm SD. NR, No response; NA, not applicable.
A

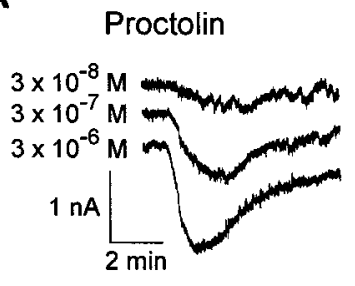

B Dose-Response Curves

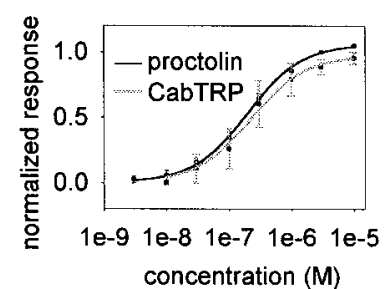

Figure 7. Dose-response curves for proctolin and CabTRP in the LP neuron. $A$, Representative voltage-clamp traces from bath application of varying concentrations of proctolin. $B$, Dose-response curves for proctolin $(n=5)$ and CabTRP $(n=3)$. For each individual experiment, peak currents were normalized to the largest response. Responses across all experiments were then averaged and plotted \pm SE. Recordings were made using TEVC in the presence of $10 \mu \mathrm{M}$ PTX and $0.1 \mu \mathrm{M}$ TTX. The fits to the data points were done to the curve $y=I_{\max } x /\left(K_{\mathrm{d}}+x\right)$, where $x$ is the concentration of the applied peptide, $I_{\max }$ is the normalized maximal current, and $K_{\mathrm{d}}$ is the dissociation constant. For proctolin, $I_{\max }=1.06 \pm$ 0.01 , and $K_{\mathrm{d}}=2.02 \pm 0.01 \times 10^{-7} \mathrm{M}$. For CabTRP, $I_{\max }=0.97 \pm 0.03$, and $K_{\mathrm{d}}=2.25 \pm 0.29 \times 10^{-7} \mathrm{M}$.

\section{DISCUSSION}

Nervous systems contain a vast number of signaling molecules, including amino acids, amines, and neuropeptides. Although extensive neuroanatomical and immunocytochemical work has demonstrated complex and rich patterns of colocalization for amines and peptides, how these substances modulate specific functional circuits remains relatively unknown. The stomatogastric nervous system contains $\sim 20$ different identified modulatory substances (Marder and Weimann, 1992; Marder et al., 1995; Christie et al., 1997a; Abbott and Marder, 1998), each of which can alter the STG motor patterns. The effects of serotonin (Kiehn and HarrisWarrick, 1992a,b; Zhang and Harris-Warrick, 1995), dopamine (Harris-Warrick et al., 1995a,b; Kloppenburg et al., 1999), and the peptide proctolin (Golowasch and Marder, 1992) have been characterized, but until now, the biophysical actions of most of the modulatory substances found in inputs to the STG were unknown.

\section{Voltage dependence of the modulator current}

We predominantly used ramps in this study because they provided a simple method for obtaining a quantitative value for $\mathrm{V}_{\text {peak }}$, which otherwise would have required interpolation among points taken at different holding potentials, and they allowed us to obtain the full $I-V$ curve during a single application of modulator. Deriving $I-V$ curves using voltage ramps can sometimes give inaccurate results depending on the voltage and time dependence of the current being characterized. Nonetheless, Figures 2 and 9 show that the voltage dependence captured in the ramps is also seen in the currents evoked at fixed holding potentials, as was described in 
A

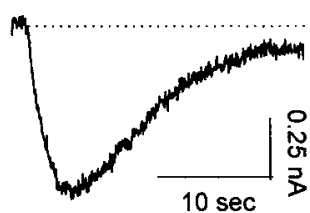

$\uparrow$

Proctolin

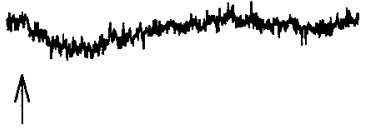

Proctolin

( $2 \times 10^{-6} \mathrm{M}$ CabTRP in bath)

B

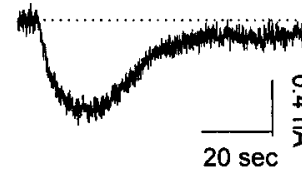

$\uparrow$

CabTRP

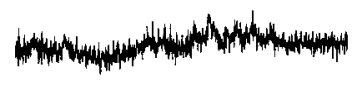

A

CabTRP

( $2 \times 10^{-6} \mathrm{M}$ Proctolin in bath)
Figure 8. Occlusion of the peptidergic responses in the LP neuron. $A$, The response to proctolin is occluded by bath application of CabTRP. $B$, The response to CabTRP is occluded by bath application of proctolin. The LP neuron was voltage-clamped at $-50 \mathrm{mV}$. The dotted line represents the baseline current. The offsets in the right traces are caused by the steady-state current produced by the bath-applied peptides. Proctolin $(A)$ and CabTRP $(B)$ were pressure-applied $\left(10^{-4} \mathrm{M}\right)$ to the ganglion neuropil. Recordings were made using TEVC in the presence of $10 \mu \mathrm{M}$ PTX and $0.1 \mu \mathrm{M}$ TTX.
Control
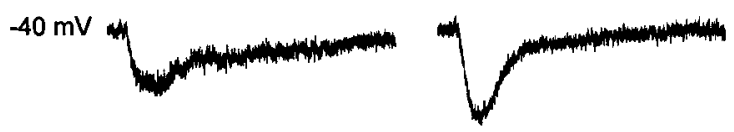

$-80 \mathrm{mV}$

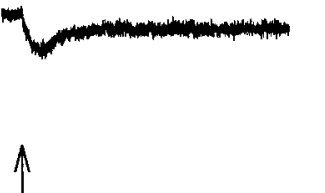

Proctolin
W-7

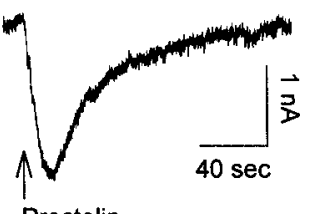

Proctolin
Figure 9. The calmodulin inhibitor W-7 (bath-applied, $3.3 \times 10^{-4} \mathrm{M}$ ) increases the amplitude of the peptidergic current and alters its voltage dependence. In control conditions, proctolin elicits a larger current at -40 than at $-80 \mathrm{mV}$. In the presence of $\mathrm{W}-7$, the amplitude of the elicited current at both membrane potentials increases, and the elicited response becomes larger at -80 than at $-40 \mathrm{mV}$. Proctolin was pressure-applied at $4 \times 10^{-4} \mathrm{M}$ to the ganglion neuropil. Recordings are from an LP neuron using TEVC in the presence of $10 \mu \mathrm{M}$ PTX and $0.1 \mu \mathrm{M}$ TTX.

previous work on the proctolin-induced current (Golowasch and Marder, 1992).

The experiments reported here demonstrate that six different substances converge on a voltage-dependent inward current whose current-voltage curve linearizes in low- $\mathrm{Ca}^{2+}$ solutions. $\mathrm{V}_{\text {peak }}$ differed for different identified cell types, although for an individual neuron, all of the peptides that acted on that neuron evoked a current with a similar voltage dependence. $\mathrm{V}_{\text {peak }}$ ranged from -55 to $-15 \mathrm{mV}$ in different cultured neurons, and the identified VD and LP neurons had statistically different $V_{\text {peak }}$ values. $V_{\text {peak }}$ for the LP neuron reported in this study is more depolarized than the value for the peak response previously reported (Golowasch and
Marder, 1992). In the previous study, the mean peak voltage was calculated using the amplitudes of responses measured in both current clamp and voltage clamp and with a variety of protocols, whereas all of the data reported here were obtained as difference currents calculated from ramps, and we assume that this discrepancy results from differences in experimental methods.

The differences in the voltage dependence of different cell types could arise from a number of different scenarios: (1) different cell types could express channels with different subunit compositions; (2) different cell types could have more or less extensive phosphorylation of the channel; and (3) some cell types could have an additional peptide-modulated voltage-dependent current that contributes to the net current as we have measured it. At present we have no way to distinguish among these possibilities, but note that within an individual neuron, all active peptides evoke currents with a similar voltage dependence, arguing that whatever mechanism is responsible for the cell-type differences, it is independent of the identity of the activating peptide.

Sharp (1994) used the dynamic clamp to apply the proctolin current to both the LP and anterior burster neurons of the STG and found that the $\mathrm{V}_{\text {peak }}$ of the artificial proctolin current had to be carefully matched to the intrinsic properties of each neuron to reproduce the actions of exogenously applied proctolin. Therefore, each neuron may tune this modulator current so that its voltage dependence is set with regard to the other voltage-dependent currents found in the neuron. For example, it is possible that the voltage dependence of the proctolin-induced current in the LP neuron is tuned to enhance the ability of the LP neuron to generate bursts and plateau properties, but the more depolarized current in the VD neuron is tuned to influence spike rate but not to enhance bursting.

\section{Where does convergence occur?}

Other examples of modulator convergence are abundant in both invertebrates (Brezina, 1988; Bolshakov et al., 1993; van Tol-Steye et al., 1997, 1999) and vertebrates (Andrade and Aghajanian, 1985; Jones, 1985; Andrade et al., 1986; Christie and North, 1988; Bley and Tsien, 1990; Nicoll et al., 1990; Cox and Dunlap, 1992; Sodickson and Bean, 1998). It is simplest to assume that the convergence of the different modulators onto the same current in this study occurs subsequent to receptor binding. The agonists studied here have very different structures, and it would be quite unexpected if they bind to the same receptor. Moreover, if they were somehow able to bind to a very promiscuous receptor, then one would predict that any neuron that responded to one of the substances would respond to all of them. Our work in culture and in the ganglion shows that this is not the case.

The finding that the peptide responses occlude each other suggests that they act on the same channels and that the convergence is occurring either at some intermediate level of the signal transduction pathway or at the level of the channel itself. This interpretation is also supported by the fact that $\mathrm{W}-7$ alters the amplitude and voltage dependence of both the proctolin and CabTRP currents. Work in other systems suggests that convergence often occurs early in the signal transduction pathway upstream from the actual ion channel (Andrade and Aghajanian, 1985; Andrade et al., 1986; Bolshakov et al., 1993; Brezina et al., 1994b; Jones et al., 1995; van Tol-Steye et al., 1999), although substances with convergent effects can act through different second messenger pathways (Elmslie, 1992; Diversé-Pierluissi and Dunlap, 1993, 1995).

Despite extensive work on the modulation of STG networks, much less is known concerning the second messenger pathways underlying that modulation. Proctolin does not appear to increase cAMP levels in STG neurons (Flamm et al., 1987; Hempel et al., 1996). The W-7 data (Fig. 9) suggest that a calmodulin-sensitive step is possibly implicated in the activation of this channel or in its modulation, but much further work will be needed to determine the signal transduction pathways activated by these substances. 


\section{Functional consequences of convergence for circuit modulation}

Dopamine and serotonin both modulate several voltage-dependent conductances in STG neurons (Kiehn and Harris-Warrick, 1992a,b; Harris-Warrick et al., 1995a,b; Zhang and HarrisWarrick, 1995; Kloppenburg et al., 1999). Therefore, it was natural to assume that many of the other modulators would also alter multiple voltage-dependent currents in STG neurons. The result reported here is interesting for two reasons. First, it is surprising that so many substances converge on the same current. Examples of this large degree of convergence are relatively rare (Sodickson and Bean, 1998). Second, it is surprising that so many of the actions of these peptides on the motor patterns generated by the STG can be attributed to modulation of a single current, as demonstrated with dynamic clamp applications of a model proctolin current, which mimic well the actions of proctolin (Sharp et al., 1993a,b; Abbott and Marder, 1998). Nonetheless, these peptides may evoke additional, as yet uncharacterized actions that are responsible for their effects on synaptic transmission (Dickinson et al., 1990; Marder et al., 1997) or could influence membrane excitability.

Our description of the response characteristics for the VD and LP neurons suggests that different neuronal types respond to various subsets of the peptides. The output of the network as a whole will be strongly influenced by the distribution of peptide receptors on different neurons. This would be a particularly useful mechanism for the selection of different motor patterns in response to nonlocalized release from neurohemal-like terminals within the STG (Kilman and Marder, 1996) or to substances that reach the STG hormonally (Christie et al., 1995).

What are the consequences for circuit modulation of the modulator convergence reported here? At first glance, the convergence of all of these modulators onto the same current appears to reduce the potential for circuit flexibility. However, the number and distribution of receptors to each substance will allow each one to produce characteristic and different actions at the network level. Additionally, these modulators could have divergent effects on other membrane currents and/or synaptic transmission, which could also help contribute to the differential network effects of these modulators. Another mechanism to allow the nervous system to maintain a wide range of outputs could be through the colocalization of various modulators. Proctolin and CabTRP are colocalized in modulatory commissural neuron 1 (MCN1), but MCN1 activation results in a different motor pattern than that evoked by other proctolin-containing neurons (Blitz et al., 1999) that contain different cotransmitters.

The extensive convergence of these modulators could also contribute to network stability. The large numbers of modulators and sites of modulatory action in the STG make it difficult to understand how networks are protected against "overmodulation." Each of the modulators studied here could produce a unique action at the level of the whole network, but because they occlude the actions of each other, the response of a given neuron to multiple modulators will be limited or held in check. Convergence may actually contribute to limiting the number of possible network configurations and, therefore, may serve as a stabilizing force.

\section{REFERENCES}

Abbott LF, Marder E (1998) Modeling small networks. In: Methods in neuronal modeling: from ions to networks, Ed 2 (Koch C, Segev I, eds), pp 361-410. Cambridge, MA: MIT.

Andrade R, Aghajanian GK (1985) Opiate- and alpha 2-adrenoceptorinduced hyperpolarizations of locus ceruleus neurons in brain slices: reversal by cyclic adenosine $3^{\prime}: 5^{\prime}$-monophosphate analogues. J Neurosci 5:2359-2364.

Andrade R, Malenka RC, Nicoll RA (1986) A G protein couples serotonin and $\mathrm{GABA}_{\mathrm{B}}$ receptors to the same channels in hippocampus. Science 234:1261-1265.

Bley KR, Tsien RW (1990) Inhibition of $\mathrm{Ca}^{2+}$ and $\mathrm{K}^{+}$channels in sympathetic neurons by neuropeptides and other ganglionic transmitters. Neuron 4:379-391.

Blitz DM, Christie AE, Coleman MJ, Norris BJ, Marder E, Nusbaum MP (1999) Different proctolin neurons elicit distinct motor patterns from a multifunctional neuronal network. J Neurosci 19:5449-5463.
Bolshakov V, Gapon SA, Katchman AN, Magazanik LG (1993) Activation of a common potassium channel in molluscan neurones by glutamate, dopamine and muscarinic agonist. J Physiol (Lond) 468:11-33.

Brezina V (1988) Guanosine 5'-triphosphate analogue activates potassium current modulated by neurotransmitters in Aplysia neurones. J Physiol (Lond) 407:15-40.

Brezina V, Evans CG, Weiss KR (1994a) Enhancement of Ca current in the accessory radula closer of Aplysia californica by neuromodulators that potentiate its contractions. J Neurosci 14:4393-4411.

Brezina V, Evans CG, Weiss KR (1994b) Activation of K current in the accessory radula closer of Aplysia californica by neuromodulators that depress its contractions. J Neurosci 14:4412-4432.

Christie AE, Skiebe P, Marder E (1995) Matrix of neuromodulators in neurosecretory structures of the crab, Cancer borealis. J Exp Biol 198:2431-2439.

Christie AE, Baldwin DH, Marder E, Graubard K (1997a) Organization of the stomatogastric neuropil of the crab, Cancer borealis, as revealed by modulator immunocytochemistry. Cell Tissue Res 288:135-148.

Christie AE, Lundquist T, Nässel DR, Nusbaum MP (1997b) Two novel tachykinin-related peptides from the nervous system of the crab Cancer borealis. J Exp Biol 200:2279-2294.

Christie MJ, North RA (1988) Agonists at mu-opioid, M2-muscarinic and $\mathrm{GABA}_{\mathrm{B}}$-receptors increase the same potassium conductance in rat lateral parabrachial neurones. Br J Pharmacol 95:896-902.

Coleman MJ, Meyrand P, Nusbaum MP (1995) A switch between two modes of synaptic transmission mediated by presynaptic inhibition. Nature 378:502-505.

Cox DH, Dunlap K (1992) Pharmacological discrimination of N-type from L-type calcium current and its selective modulation by transmitters. J Neurosci 12:906-914.

Dickinson PS, Mecsas C, Marder E (1990) Neuropeptide fusion of two motor pattern generator circuits. Nature 344:155-158.

Diversé-Pierluissi M, Dunlap K (1993) Distinct, convergent second messenger pathways modulate neuronal calcium currents. Neuron 10:753-760.

Diversé-Pierluissi M, Dunlap K (1995) Interaction of convergent pathways that inhibit N-type calcium currents in sensory neurons. Neuroscience 65:477-483.

Dunlap K, Fischbach GD (1978) Neurotransmitters decrease the calcium component of sensory neurone action potentials. Nature 276:837-839.

Elmslie KS (1992) Calcium current modulation in frog sympathetic neurones: multiple neurotransmitters and $G$ proteins. J Physiol (Lond) 451:229-246.

Flamm RE, Fickbohm D, Harris-Warrick RM (1987) cAMP elevation modulates physiological activity of pyloric neurons in the lobster stomatogastric ganglion. J Neurophysiol 58:1370-1386.

Golowasch J, Marder E (1992) Proctolin activates an inward current whose voltage dependence is modified by extracellular $\mathrm{Ca}^{2+}$. $\mathrm{J}$ Neurosci 12:810-817.

Gudermann T, Schöneberg T, Schultz G (1997) Functional and structural complexity of signal transduction via G-protein-coupled receptors. Annu Rev Neurosci 20:399-427.

Harris-Warrick RM, Marder E, Selverston AI, Moulins M, eds (1992) Dynamic biological networks. The stomatogastric nervous system. Cambridge, MA: MIT.

Harris-Warrick RM, Coniglio LM, Barazangi N, Guckenheimer J, Gueron S (1995a) Dopamine modulation of transient potassium current evokes phase shifts in a central pattern generator network. J Neurosci 15:342-358.

Harris-Warrick RM, Coniglio LM, Levini RM, Gueron S, Guckenheimer J (1995b) Dopamine modulation of two subthreshold currents produces phase shifts in activity of an identified motoneuron. J Neurophysiol 74:1404-1420.

Hempel CM, Vincent P, Adams SR, Tsien RY, Selverston AI (1996) Spatio-temporal dynamics of cyclic AMP signals in an intact neural circuit. Nature 384:166-169.

Hidaka H, Yamaki T, Naka M, Tanaka T, Hayashi H, Kobayashi R (1980) Calcium-regulated modulator protein interacting agents inhibit smooth muscle calcium-stimulated protein kinase and ATPase. Mol Pharmacol 17:66-72.

Hille B (1992) G protein-coupled mechanisms and nervous signaling. Neuron $9: 187-195$.

Hille B (1994) Modulation of ion-channel function by G-protein-coupled receptors. Trends Neurosci 17:531-536.

Hooper SL, Marder E (1984) Modulation of a central pattern generator by two neuropeptides, proctolin and FMRFamide. Brain Res 305:186-191.

Itoh H, Hidaka H (1984) Direct interaction of calmodulin antagonists with $\mathrm{Ca}^{2+} /$ calmodulin-dependent cyclic nucleotide phosphdiesterase. J Biochem 96:1721-1726.

Jones SW (1985) Muscarinic and peptidergic excitation of bull-frog sympathetic neurones. J Physiol (Lond) 366:63-87.

Jones S, Brown DA, Milligan G, Willer E, Buckley NJ, Caulfield MP (1995) Bradykinin excites rat sympathetic neurons by inhibition of $M$ current through a mechanism involving $B 2$ receptors and $\mathrm{G}$ alpha $\mathrm{q} / 11$. Neuron 14:399-405.

Kaczmarek LK, Levitan IB (1987) Neuromodulation: the biochemical control of neuronal excitability. New York: Oxford UP. 
Kiehn O, Harris-Warrick RM (1992a) Serotonergic stretch receptors induce plateau properties in a crustacean motor neuron by a dualconductance mechanism. J Neurophysiol 68:485-495.

Kiehn O, Harris-Warrick RM (1992b) 5-HT modulation of hyperpolarization-activated inward current and calcium-dependent outward current in a crustacean motor neuron. J Neurophysiol 68:496-508.

Kilman VL, Marder E (1996) Ultrastructure of the stomatogastric ganglion neuropil of the crab, Cancer borealis. J Comp Neurol 374:362-375

Kloppenburg P, Levini RM, Harris-Warrick RM (1999) Dopamine modulates two potassium currents and inhibits the intrinsic firing properties of an identified motor neuron in a central pattern generator network J Neurophysiol 81:29-38.

Kupfermann I (1991) Functional studies of cotransmission. Physiol Rev 71:683-732.

Levitan IB (1988) Modulation of ion channels in neurons and other cells. Annu Rev Neurosci 11:119-136.

Levitan IB (1994) Modulation of ion channels by protein phosphorylation and dephosphorylation. Annu Rev Physiol 56:193-212.

Marder E (1987) Neurotransmitters and neuromodulators. In: The crustacean stomatogastric nervous system: a model for the study of centra nervous systems (Selverston AI, Moulins M, eds), pp 263-300. New York: Springer.

Marder E (1998) From biophysics to models of network function. Annu Rev Neurosci 21:25-45.

Marder E, Calabrese RL (1996) Principles of rhythmic motor pattern generation. Physiol Rev 76:687-717.

Marder E, Eisen JS (1984) Transmitter identification of pyloric neurons: electrically coupled neurons use different neurotransmitters. J Neurophysiol 51:1345-1361.

Marder E, Hooper SL (1985) Neurotransmitter modulation of the stomatogastric ganglion of decapod crustaceans. In: Model neural networks and behavior (Selverston AI, ed), pp 319-337. New York: Plenum.

Marder E, Weimann JM (1992) Modulatory control of multiple task processing in the stomatogastric nervous system. In: Neurobiology of motor programme selection (Kien J, McCrohan C, Winlow B, eds), pp 3-19. New York: Pergamon.

Marder E, Hooper SL, Siwicki KK (1986) Modulatory action and distribution of the neuropeptide proctolin in the crustacean stomatogastric nervous system. J Comp Neurol 243:454-467.

Marder E, Christie AE, Kilman VL (1995) Functional organization of cotransmission systems: lessons from small nervous systems. Invert Neurosci $1: 105-112$.

Marder E, Jorge-Rivera JC, Kilman V, Weimann JM (1997) Peptidergic modulation of synaptic transmission in a rhythmic motor system. In: The synapse: in development, health, and disease (Festoff BW, Hantaï D, Citron BA, eds), pp 213-233. Greenwich, CT: JAI.

Marder E, Swensen AM, Blitz DM, Christie AE, Nusbaum MP (2000) Convergence and divergence of cotransmitter systems in the crab stomatogastric nervous system. In: Frontiers in crustacean neurobiology (Wiese $\mathrm{K}$, ed), in press.
Nicoll RA, Malenka RC, Kauer JA (1990) Functional comparison of neurotransmitter receptor subtypes in mammalian central nervous system. Physiol Rev 70:513-565.

Nusbaum MP, Marder E (1988) A neuronal role for a crustacean red pigment concentrating hormone-like peptide: neuromodulation of the pyloric rhythm in the crab, Cancer borealis. J Exp Biol 135:165-181.

Selverston AI, Russell DF, Miller JP, King DG (1976) The stomatogastric nervous system: structure and function of a small neural network. Prog Neurobiol 7:215-290.

Sharp AA (1994) Single neuron and small network dynamics explored with the dynamic clamp. PhD thesis, Brandeis University.

Sharp AA, O'Neil MB, Abbott LF, Marder E (1993a) Dynamic clamp: computer-generated conductances in real neurons. $\mathrm{J}$ Neurophysiol 69:992-995.

Sharp AA, O’Neil MB, Abbott LF, Marder E (1993b) The dynamic clamp: artificial conductances in biological neurons. Trends Neurosci 16:389-394

Sodickson DL, Bean BP (1998) Neurotransmitter activation of inwardly rectifying potassium current in dissociated hippocampal CA3 neurons: Interactions among multiple receptors. J Neurosci 18:8153-8162.

Swensen A, Marder E (1998) Convergent modulatory peptides act on the same voltage-dependent current in stomatogastric neurons of Cancer borealis. Soc Neurosci Abstr 24:359.

Turrigiano GG, Marder E (1993) Modulation of identified stomatogastric ganglion neurons in primary cell culture. J Neurophysiol 69:1993-2002.

Turrigiano G, Abbott LF, Marder E (1994) Activity-dependent changes in the intrinsic properties of cultured neurons. Science 264:974-977.

Turrigiano GG, LeMasson G, Marder E (1995) Selective regulation of current densities underlies spontaneous changes in the activity of cultured neurons. J Neurosci 15:3640-3652.

van Tol-Steye H, Lodder JC, Planta RJ, van Heerikhuizen H, Kits KS (1997) Convergence of multiple G-protein-coupled receptors on a single type of potassium channel. Brain Res 777:119-130.

van Tol-Steye H, Lodder JC, Mansvelder HD, Planta RJ, van Heerikhuizen H, Kits KS (1999) Roles of G-protein $\beta \gamma$, arachidonic acid, and phosphorylation in convergent activation of an $\mathrm{S}$-like potassium conductance by dopamine, Ala-Pro-Gly-Trp- $\mathrm{NH}_{2}$, and Phe-Met-Arg-Phe- $\mathrm{NH}_{2}$. J Neurosci 19:3739-3751.

Weimann JM, Marder E, Evans B, Calabrese RL (1993) The effects of SDRNFLRFamide and TNRNFLRFamide on the motor patterns of the stomatogastric ganglion of the crab Cancer borealis. J Exp Biol 181:1-26.

Weimann JM, Skiebe P, Heinzel H-G, Soto C, Kopell N, Jorge-Rivera JC, Marder E (1997) Modulation of oscillator interactions in the crab stomatogastric ganglion by crustacean cardioactive peptide. J Neurosci 17:1748-1760.

Zhang B, Harris-Warrick RM (1995) Calcium-dependent plateau potentials in a crab stomatogastric ganglion motor neuron. I. Calcium current and its modulation by serotonin. J Neurophysiol 74:1929-1937. 